УДК 316.6

\title{
НОВАЯ РЕГИОНАЛЬНАЯ ИДЕНТИЧНОСТЬ (НА ПРИМЕРЕ ВХОЖДЕНИЯ ЗАБАЙКАЛЬСКОГО КРАЯ И РЕСПУБЛИКИ БУРЯТИЯ В ДФО)
}

Русанова Анна Алексеевна кандидат педагогических наук, доцент заведующая кафедрой социологии Лаврикова Виктория Николаевна кандидат социологических наук, доцент доцент кафедры социологии

Филиппова Елена Владимировна старший преподаватель кафедры социологии ФГБОУ ВО «Забайкальский государственный университет»

Аннотация: Статья посвящена исследованию региональной идентичности, которая рассматривается авторами не как традиционно и исторически обоснованная территориально-культурная идентификация, а как искусственно созданная географическая, экономически обусловленная территориальная реальность. В статье раскрываются научные подходы в изучении категории «региональная идентичность» и представлены эмпирические данные по заявленной теме.

Статья выполнена при финансовой поддержке РФФИ и ЭИСИ в рамках научного проекта № 21-011-31524.

Ключевые слова: идентичность, региональная идентичность, ментальность, Дальневосточный регион.

\section{A NEW REGIONAL IDENTITY}

(ON THE EXAMPLE OF THE ENTRY OF THE TRANS-BAIKAL TERRITORY AND THE REPUBLIC OF BURYATIA INTO THE FAR EASTERN FEDERAL DISTRICT)

Rusanova Anna Alekseevna Lavrikova Victoria Nikolaevna Filippova Elena Vladimirovna 
Abstract: The article is devoted to the study of regional identity, which is considered by the authors not as a traditionally and historically grounded territorial and cultural identification, but as an artificially created geographical, economically conditioned territorial reality. The article reveals scientific approaches to the study of the category "regional identity" and presents empirical data on the stated topic.

The article was carried out with the financial support of the RFBR and EISI within the framework of the scientific project No. 21-011-31524.

Key words: identity, regional identity, mentality, Far Eastern region.

Тема региональной идентичности достаточно дискуссионная в социологии. Это связано, в первую очередь, с междисциплинарностью самого понятия «региональная идентичность». Оно включает в себя философский, политический, экономический, географический и, конечно же, социологический аспекты изучения. Каждая из выше перечисленных наук изучает данное явление при помощи и общенаучного, и собственного методологического и инструментального аппарата. Таким образом, существует множество подходов в исследовании региональной идентичности и, тем более, в ее интерпретации.

Нередко региональная идентификация человека связывается с его естественной потребностью в определенном месте поселения, укорененности на конкретной географической территории. Именно здесь формируются особые социокультурные отношения, которые ассоциируются с понятием «малая родина». Ученых, придерживающихся данного понимания региональной идентичности, в первую очередь интересуют групповые и межгрупповые феномены в рамках осмысления «коллективного Я» [1].

Существуют и другие мнения в осмыслении феномена региональной идентичности. Например, В.Н. Стрелецкий, приравнивая региональную идентичность к территориальной, считает, что местечковое - земляческое районное - национальное самосознания как бы образуют разные «концентры» территориальной идентичности - полимасштабной и многоуровневой системы [2], Регион, по мнению ученого, является гомогенным пространством, выделенным самими людьми, имеющим физико-географическую, хозяйственную, этнокультурную и языковую общность, а также общность исторической судьбы [3]. 
С точки зрения другой группы ученых, выделять региональную идентичность как самостоятельную идентичность не вполне корректно. Они выделяют ей место в иерархии идентичностей, причем, рассматривают региональную идентичность в качестве одного из уровней территориальной идентичности [4].

Существуют и такие подходы, при которых региональная идентичность отождествляется с каким-либо другим видом идентичности: Ачкасов В.А. считает региональную идентичность вариантом этнической [5]. Кувенева Т.Н. и Манаков А.Г. - национальной [6].

В отдельное направление можно выделить управленческий аспект осмысления региональной идентичности. Например, 3.А. Жаде и Е.В. Головнёва считают, что региональная идентичность зависит от уровня экономического, политического культурного развития региона и является элементом политического управления [7; 8]. Эту же идею продолжает Н.П. Крылов, по мнению которого региональная идентичность - это воля к жизни и развитию данной территории, способность к социокультурной, гражданской и экономической активности, выступающая предпосылкой реализации региональных (местных) интересов [9].

Авторам данной статьи в большей степени импонирует подход Чернышова Ю.Г. и Киселёва К.В., которые связывают данное понятие с имиджем конкретного региона [10]. Это обосновано темой исследования и необходимостью введения в контекстуальный оборот понятия «новая региональная идентичность», под которой понимается искусственно созданная регионально-территориальная реальность, связанная с целью создания центров геополитических, экономических, социальных процессов.

В 2018 году Забайкальский край и Республика Бурятия вошли в состав Дальневосточного федерального округа (ДФО), что связано с актуализацией вопросов смещения стратегических интересов России в сторону Сибири и Дальнего Востока - «Разворот на восток». Это событие стало, во многом, поворотным в жизни этих регионов с точки зрения вовлечения человеческого, природно-ресурсного, транспортно-логистического потенциала и формирования новых социально-экономических, социально-политических и социокультурных условий. По сути, создается уникальное региональное пространство, которое «аккумулирует результаты происходящего в нем этнокультурного взаимодействия, что способствует как сохранению, так и 
последовательному развитию локальных культур, появлению новых форм массового сознания, в том числе территориальной идентичности» [11]. В этом смысле, формирование новой региональной идентичности может стать фактором устойчивого развития этой новой социально-политической территории.

Забайкальский край и Республика Бурятия достаточно специфичны, отличаются особой ментальностью, этно-национальным и этно-культурным своеобразием. Но, в то же время, их объединяют общие проблемы: экономические, управленческие, экологические и др. Например, одной из ключевых является проблема миграционной подвижности населения: как тенденция оттока в более престижные по социально-экономическим условиям регионы, так и притока из других, менее престижных регионов России и бывших советских республик. Формирование регионального социума происходит в условиях сложной мозаичности национальностей, культурных традиций, вероисповедания, норм быта и общежития. Поэтому формирование общей новой идентичности приобретает особое значение.

Результаты опросов молодого населения Забайкалья и Бурятии, проведенные авторским коллективом в 2021 году в ходе социологического исследования, выполненного при финансовой поддержке РФФИ и ЭИСИ в рамках научного проекта № 21-011-31524, показали, что процесс формирования новой региональной идентичности только начинается.

Например, вопросы о том, улучшится ли жизнь региона в связи с вхождением в Дальневосточный регион, и какие изменения в жизни молодых людей непосредственно связаны с этим процессом, вызвали затруднение у большинства респондентов: более $60 \%$ респондентов выбрали позиции «не знаю» и «затрудняюсь ответить» (данные здесь и далее по тексту приводятся в усредненном по региону виде, т.к. различия во мнениях жителей Забайкальского края и Республики Бурятия не превышают погрешности).

С целью верификации результатов опроса с точки зрения идентификационных профилей молодым людям было предложено выразить свое внутреннее ощущение близости с понятиями-символами, отражающими определенные социальные круги: «Я - человек» (планетарный уровень), «Я россиянин» (государственный уровень), «Я - забайкалец» (региональный уровень), «Я - дальневосточник» (региональный уровень - новая региональная реальность), «Я - житель своего поселения (города, поселка, 
села)» (поселенческий уровень) «Я - студент» (профессиональный уровень), «Я - сын/дочь» (личностный уровень), «Я - друг/подруга» (личностный уровень). Результаты представлены в таблице 1.

Таблица 1

Идентификационные профили студентов

\begin{tabular}{|c|c|c|c|c|}
\hline & $\begin{array}{c}\text { В полной } \\
\text { мере }\end{array}$ & $\begin{array}{c}\text { В } \\
\text { определенной } \\
\text { мере }\end{array}$ & $\begin{array}{c}\text { Нет } \\
\text { ощущения } \\
\text { близости }\end{array}$ & $\begin{array}{c}\text { Затрудняюсь } \\
\text { ответить }\end{array}$ \\
\cline { 2 - 5 } \% от всех опрошенных \\
\hline $\begin{array}{c}\text { Я - человек планеты } \\
\text { Земля }\end{array}$ & 31 & 34 & 16 & 19 \\
\hline Я - россиянин & 39 & 41 & 15 & 5 \\
\hline $\begin{array}{c}\text { Я - житель своего(-й) } \\
\text { края/республики }\end{array}$ & 53 & 34 & 10 & 3 \\
\hline Я - дальневосточник & 0 & 12 & 79 & 5 \\
\hline $\begin{array}{c}\text { Я - житель своего } \\
\text { поселения (города, } \\
\text { поселка, села) }\end{array}$ & 57 & 26 & 12 & 3 \\
\hline Я - друг/подруга & 79 & 13 & 5 & 7 \\
\hline Я - сын/дочь & 93 & 0 & 0 & 9 \\
\hline
\end{tabular}

Опрос выявил достаточно высокий уровень локальной региональной идентификации молодежи. Большинство респондентов в полной мере и в определенной мере идентифицируют себя с жителями своей территории. В данном случае можно говорить о так называемой культурном уровне региональной идентификации, который связан с определенной территориальной ментальностью, принадлежностью к региональному сообществу на основе общей истории, культурных символов, национальных традиций и ценностей и т.п.

Новая региональная реальность (Я - дальневосточник), искусственно созданная с определенными государственными целями, еще не вошла в сознание молодежи, не воспринимается ими как «близкая» и «родная. По сути, это стратегический уровень региональной идентичности, с конструированием нового регионального имиджа, позиционированием нового территориального образования, изобретением новых территориальных традиций, формированием новой символической политики. 
Причиной не сформированности новой региональной идентичности, на наш взгляд, является недостаточное позиционирование новой, искусственно созданной, территориальной реальности. Было выяснено, что молодые люди слабо осведомлены о новых социально-экономических, социальнополитических процессах, происходящих в регионе, что ни в коей мере не способствует формированию новой региональной идентичности.

На наш взгляд, необходим особый политический курс по конструированию позитивного регионального имиджа, формированию региональных амбиций, практическому использованию региональной идентичности, что, несомненно, будет способствовать решению чисто прагматичных задач региональной власти: формированию инвестиционной привлекательности, улучшению социального климата, сокращению утечки человеческого капитала.

\section{Список литературы}

1. Герасимов А.С. Подходы к исследованию региональной идентичности в отечественной науке // Вест. Псковского гос. ун-та. Серия «Естественные и физико-математические науки». Псков: ПсковГУ - 2013. № 3. - C. 57-63.

2. Стрелецкий В.Н. Культурный регионализм: сущность понятия, проблемы изучения и система индикаторов // Псковский регионологический журнал. № 14. Псков: Изд-во ПсковгУ, 2012. С. 9-21. 24.

3. Стрелецкий В.Н. Этнокультурные предпосылки регионализации в России // Регионализация в развитии России: географические процессы и проблемы. М.: Эдиториал УРСС, 2011. С. 11-38.

4. Алехина С.Н., Каргаполова Е.В. Социокультурные образы дома в менталитете современной российской молодежи // Научные ведомости. Сер. Философия. Социология. Право. - 2010. - № 20 (19). Выпуск 4. - С. 186-195.

5. Ачкасов В.А. Региональная идентичность в российском политическом пространстве: «калининградский казус»// Политэкс: Политическая экспертиза, 2005. № 1.

6. Кувенева Т.Н., Манаков А.Г. Формирование пространственных идентичностей в порубежном регионе // Социологические исследования («СОЦИС»). 2003. № 7. 
7. Жаде 3.А. Россия в поисках региональной идентичности // Вестник Моск. Ун-та. Серия 12. Политические науки. 2007. № 6.

8. Головнёва Е.В. Региональная идентичность: теоретические аспекты изучения // Уральский экономический вестник. 2013.

9. Крылов Н.П. Региональная идентичность в Европейской России. М.: Новый хронограф. 2010. - 240 с.

10. Чернышов Ю.Г. Имидж региона и региональная идентичность (на примере Алтайского края) // Вестник Пермского университета. Серия «Политология». Пермь. 2011.

11. Симонян Р.Х. Концепция мезоуровня применительно к региону // Социологические исследования. 2010. № 5(313). С. 52-61.

(C) А.А. Русанова, В.Н. Лаврикова, Е.В. Филиппова, 2021 